\title{
Consortium of Industrial Agroforestry: an institutional mechanism for sustaining agroforestry in India
}

\author{
K. T. Parthiban*, R. Jude Sudhagar, C. Cinthia Fernandaz and N. Krishnakumar
}

India is among the few tropical countries which have been reporting a progressive increase in forest cover over the past two decades. Our country being a major consumer of wood and wood products, the role of agroforestry as a viable land-use system is gaining significant attention owing to its contribution towards meeting domestic and industrial wood requirements. Growing demand coupled with legal issues in wood supply from Government-owned forests has resulted in a total mismatch between demand and supply of wood and wood products. The Tamil Nadu Agricultural University (TNAU) conceived and implemented 'a value chain model' and created sustainability in industrial wood generation and supply in the state by involving a wide range of stakeholders. In order to strengthen the value chain and promote agroforestry based on the objectives envisaged in the National Agroforestry Policy of 2014, TNAU established a 'Consortium of Industrial Agroforestry' (CIAF) by linking stakeholders to address the issues related to production, processing and consumption in agroforestry. Keeping in line with the guidelines provided in the National Agroforestry Policy of 2014, CIAF has successfully established decentralized institutions for supply of quality planting materials to the farmers besides facilitating organized plantation developers, harvesting and marketing institutions. The activities of CIAF have paved the way for creating the much needed database in tree cultivation, development of price supportive mechanism for important farm-grown industrial wood species and reducing the risks faced by tree growers through innovative approaches like tree insurance and value addition technologies. This consortium-mode value-chain model in agroforestry holds great potential for adoption and replication across India, which would help create self-reliance in raw material security besides augmenting tree cover in the country.

Keywords: Agroforestry, consortium approach, industrial wood, value chain model.

FORESTS in India have played a significant role in meeting the domestic and industrial wood requirements before the enactment of the Forest Conservation Act, 1980 and the National Forest Policy (1988). Owing to policy and legal implications, there has been a paradigm shift in the forest management strategy of the country with more emphasis on conservation-oriented management, which has resulted in restricted supply of wood from natural forests ${ }^{1}$. India being one of the major consumers in the Asia-Pacific region, it is estimated that the country would need 152 million $\mathrm{m}^{3}$ of wood by 2020 (ref. 2). This demand has been estimated for 12 organized wood-based industries and does not include

The authors are in the Department of Agroforestry, Forest College and Research Institute, Tamil Nadu Agricultural University, Mettupalayam 641301 , India.

*For correspondence. (e-mail: ktparthi2001@gmail.com) fuelwood demand of the country, which is also on the rise.

In 2010, the world's agricultural lands occupied $4889 \mathrm{~m} \mathrm{ha}$, an increase of 7\% (311 m ha) since 1970 (ref. 3), whereas agricultural land area has decreased by $53 \mathrm{M}$ ha since 2000 (ref. 4). Increasing wood demand coupled with changes in land-use pattern have necessitated significant interest towards agroforestry, a land-use system which is being practised across the country in various forms since time immemorial.

Though agroforestry is an age-old practice as an important form of subsistence farming, in the recent past it is valued as a commercial and profitable land-use system across the world. Approximately, 1.2 billion people $(20 \%$ of the world's population) depend directly on agroforestry products and services in rural and urban areas of developing countries ${ }^{5}$. Agroforestry systems are superior to other land uses at the global, regional, watershed and farm scales since they optimize trade-offs between 
increased food production, poverty alleviation and environmental conservation ${ }^{6}$.

The current area under agroforestry is of the order of $400 \mathrm{~m} \mathrm{ha}$, of which $300 \mathrm{~m} \mathrm{ha}$ is 'arable land' and $100 \mathrm{~m}$ ha "forest land" ${ }^{7,8}$. It is estimated that an additional $630 \mathrm{~m}$ ha of croplands and grasslands could be converted into agroforestry, primarily in the tropics 9 . Food and Agricultural Organisation (FAO) has also emphasized that agroforestry must be integrated in the Clean Development Mechanism (CDM) to broaden the scope of agroforestry. In India, several traditional agroforestry systems are successfully established with the tree-crop combination of Acacia nilotica with paddy ${ }^{10}$; as well as mango and teak with wheat and rice in the Kumaun region ${ }^{11}$. Similarly, home garden-based agroforestry is a successful land-use system in Central Himalaya ${ }^{12}$, which attests the significance of agroforestry in India.

Recognizing the growing importance of agroforestry, the Government of India directed wood-based industries to generate their own raw material in the National Forest Policy of 1988 (ref. 13). However, policy directives were not taken seriously by many wood-based industries, barring a few exceptions. Growing demand for wood and wood products, increasing interest in agroforestry and legal issues in wood supply from Government-owned forests resulted in a total mismatch between demand and supply of wood and wood products ${ }^{14}$.

Under such circumstances, the Tamil Nadu Agricultural University (TNAU) conceived and implemented 'a value chain model' to create sustainability in raw materials generation and supply in the state by involving a wide range of stakeholders. This model of industrial agroforestry was implemented between 2008 and 2014, which witnessed successful establishment of over 70,000 ha of organized plantations in Tamil Nadu (TN) ${ }^{1}$. To sustain the positive impacts generated by this value chain model, an institutional mechanism called 'Consortium of Industrial Agroforestry' (CIAF) was established by TNAU, which is the first of its kind in the country and addresses the issues related to production, processing and consumption in agroforestry. This article discusses the genesis, organizational structure, activities and achievements of CIAF, which could act as a model for the rest of the country for adoption with necessary modifications for promoting and furthering the objectives of the government in agroforestry sector of the country.

\section{Agroforestry - issues and constraints}

Agroforestry is plagued with a wide range of issues that extend from production to consumption, which have also been acknowledged in the National Agroforestry Policy of 2014 (ref. 15). In Figure 1, various constraints faced by tree-growing farmers and the consuming industries are identified and documented sector-wise.

\section{Conceptualization of Consortium of Industrial Agroforestry}

The National Forest Policy of 1988 directed wood-based industries to generate their own raw material resources rather than depending on the Forest Department for their wood requirements. However, the policy guidelines were not taken seriously by most of the wood-based industries, except a few paper industries. Subsequently, Government of India announced an exclusive Agroforestry Policy in 2014, which identified 10 strategies to promote agroforestry in the country. To address all the issues envisaged in the National policies, TNAU pioneered by establishing the CIAF on 21 March 2015, which has successfully linked various stakeholders in the industrial agroforestry value chain, and has been carrying out multifarious activities for the past three years in TN.

\section{Objectives and activities of the Consortium}

The Consortium aims to create sustainable and valueadded agroforestry initiatives with the following objectives:

- Network and establish linkages with all stakeholders to augment the production to consumption system (PCS) in industrial agroforestry.

- Promote effective collaboration among public agencies, private industries and organizations engaged in industrial agroforestry.

- Develop suitable research and development (R\&D) mechanism for industrial agroforestry in consultation with the Consortium partners.

- Ensure self-reliance in raw material supply and augment associated socio-economic and environmental issues.

- Formulate and recommend policy guidelines for promotion of industrial agroforestry.

\section{Activities and achievements of the Consortium}

CIAF primarily aims to resolve the issues in PCS in agroforestry through systematic R\&D mechanism. This approach has made several stakeholders across the country enroll as members of the Consortium, whose present strength is 205 . Figure 2 provides details of the members.

\section{Institutions for production of quality planting materials}

The CIAF has created 12 decentralized institutions, viz. nurseries and clonal production centres, which mass multiply over 18 million plants annually, thus ensuring the availability of quality planting material in a decentralized 


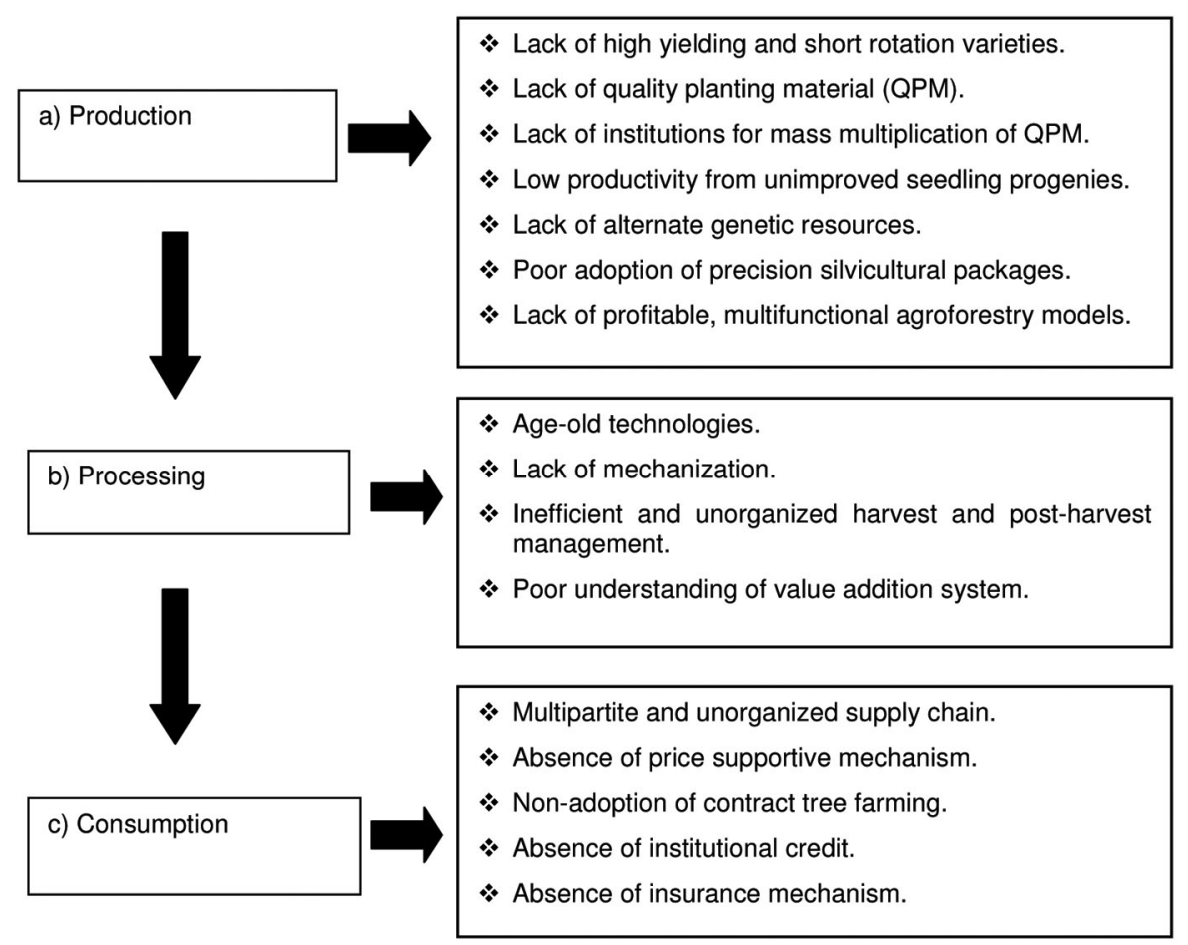

Figure 1. Constraints and problems in production to consumption system in agroforestry.

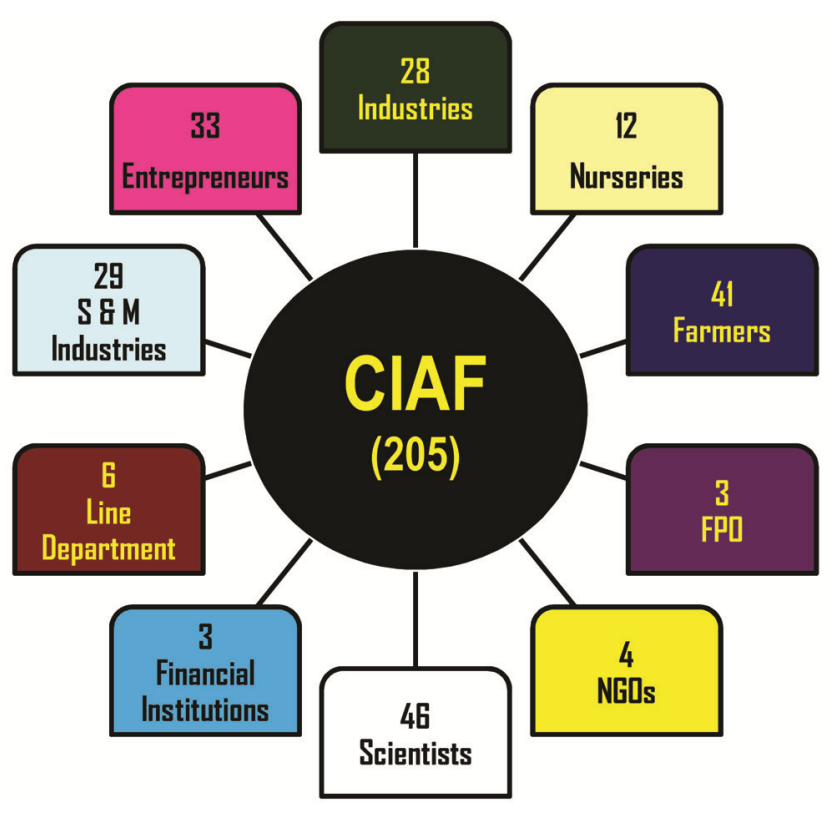

Figure 2. Composition of Consortium of Industrial Agroforestry.

manner as envisaged in the National Agroforestry policies.

\section{Organized plantation developers}

One of the major problems faced by farmers and treegrowers is the shortage of labour coupled with timely plantation establishment. This practical constraint was resolved by organizing capacity-building programmes to the Consortium members on modern plantation development technologies, which ultimately helped them evolve as organized plantation developers across TN. Eleven such plantation developers groomed by CIAF have been responsible for establishing over 5000 acres of agroforestry plantations annually. Table 1 shows a list of these institutions along with the annual area of plantations established.

Plantation developers of the Consortium ensure availability of skilled labour for manual planting as well as machines for mechanized planting, which has created significant positive impact among farmers/tree-growers of TN.

\section{Harvesting and marketing institutions}

The farmers and tree-growers also face problems with respect to harvesting, transportation and marketing of farm-grown trees. In most cases, particularly in TN, harvesting of trees for multifarious uses was restricted to a specific group of communities, who usually practised manual felling with axe. Manual felling results in considerable quantum of wood wastage leading to respective loss of due economic returns coupled with the absence of decentralization of felling institutions, which hinders the expansion of forestry/agroforestry plantations. To resolve this issue and reduce logging-related wood loss, 
Table 1. List of plantation and felling institutions

\begin{tabular}{|c|c|}
\hline Plantation developers/felling institutions & $\begin{array}{l}\text { Area planted (acres)/wood } \\
\text { harvested (tonnes/year) }\end{array}$ \\
\hline \multicolumn{2}{|l|}{ Plantation developers } \\
\hline Evergreen Plantations, Manaparai, Trichy district & 1000 \\
\hline P.K.S. Developers, Namakkal district & 1000 \\
\hline Green Land Foundation, Thanjavur district & 1000 \\
\hline Agroforestry Producer Company, Coimbatore district & 500 \\
\hline Agrocorp, Hyderabad & 100 \\
\hline Siva Sakthi Farms, Sivagangai district & 250 \\
\hline Raja Nursery, Cuddalore district & 250 \\
\hline Tree Project, Theni district & 250 \\
\hline Sri Vaari Plantation, Villupuram district & 250 \\
\hline Chinnarosa Plantation Developer, Vellore district & 100 \\
\hline Priya Nursery, Sivagangai district & 1000 \\
\hline Total area planted & 5700 \\
\hline \multicolumn{2}{|l|}{ Felling institutions } \\
\hline Sathyamoorthy Felling Group, Thanjavur district & 10,000 \\
\hline Perumal Timber Mart, Anthiyur, Erode district & 40,000 \\
\hline Thangavel Woods Traders, Sathyamangalam, Erode district & 3000 \\
\hline Agrocorp, Hyderabad & 2500 \\
\hline Saravanan Felling Group, Vellore district & 500 \\
\hline Forestry and Agroforestry Network, Coimbatore, Karur, Sivagangai, Erode district & 250 \\
\hline Coimbatore District Agroforestry Producer Company, Coimbatore district & 50 \\
\hline Bannari Traders, Sathyamangalam, Erode district & 5000 \\
\hline Manohar Felling Group, Erode district & 15,000 \\
\hline Evergreen Plantations, Trichy district & 25,000 \\
\hline Total wood harvested & 101,300 \\
\hline
\end{tabular}

the Consortium conceived the idea of setting-up felling institutions from among its members. These institutions were provided with necessary capacity building regarding the principles and practices of modern logging techniques, including hands-on training in the operation of the latest machineries available. Besides improving the harvest efficiency and reducing human drudgery, these institutions have also enabled decentralized availability of felling groups which harvest over 1 lakh tonnes of industrial wood per annum in TN. Many of these groups also undertake transportation and marketing of harvested wood, thereby providing the farmers with economic returns at the farm itself. Table 1 provides the details of these felling institutions and their annual capacity.

\section{Organized wood-based industries for marketing of industrial wood}

Success of agroforestry has been widely questioned for lack of marketing facilities, which is cited to be the key reason. To overcome this constraint, CIAF has identified potential wood-based industries and has created market base for a wide range of farm-grown trees. Table 2 shows the major industries and their wood requirement. These industries are linked in the Consortium and facilitate marketing of farm grown trees.

\section{Development of price supportive mechanism}

Unlike agriculture and horticulture, there has been a lack of price supportive mechanism for farm-grown trees. Till the recent past, wood-based industries seldom indicated the price of wood (species-wise), and hence tree-growing farmers were not aware of the pricing pattern for woodgrowing in their farmlands. Surveys conducted by the Consortium indicated the absence of a price supportive mechanism, which hampered the expansion of agroforestry in TN. This issue was earnestly addressed by establishing a price support system in the 'organized contract farming mode' for farm-grown trees. Wood price for various industrial wood species has been fixed based on mutual consultations, besides taking a cue from the prevailing local wood market prices. Post adoptions of price supportive system in TN, studies conducted by CIAF and woodbased industries have indicated quantum increase in area under tree husbandry through agroforestry.

\section{Value addition technologies}

CIAF is also keen on developing a viable system for enhancing value addition of plantation and industrial wood residues. It is estimated that from 1 ha of organized Casuarina plantation, around 5 tonnes of plantation residues is produced. In Eucalyptus, for every tonne of wood 
Table 2. Consortium of Industrial Agroforestry-linked wood-based industries

\begin{tabular}{|c|c|c|}
\hline Wood-based industries & Species & Price (Rs) \\
\hline \multirow[t]{3}{*}{ Suresh Timbers, Elumalai, Madurai district } & Teak (30-45 inch and above) & $20,000-25,000$ \\
\hline & Gmelina (25 inch and above) & $8000-10,000$ \\
\hline & Leucaena leucocephala (18 inch and above) & $5000-5500$ \\
\hline \multirow{4}{*}{$\begin{array}{l}\text { Tamil Nadu Newsprints and Papers Limited, Kagithapuram } \\
\text { Seshasayee Paper and Boards Ltd, Pallipalayam }\end{array}$} & Casuarina spp. & 4200 \\
\hline & & (debarked) \\
\hline & Eucalyptus spp. & $5500-6000$ \\
\hline & Melia dubia & $\begin{array}{r}4200-4400 \\
\text { (debarked) }\end{array}$ \\
\hline \multirow{3}{*}{$\begin{array}{l}\text { Century Plyboards (I) Ltd, Chennai; Ambiply Panels and Doors, } \\
\text { Mettupalayam; Maxbond Plywoods, Pollachi; } \\
\text { Asian Timbers, Pollachi; Sri Ranga Ply Industries, Mettupalayam }\end{array}$} & Eucalyptus (18 inch and above) & $5500-6000$ \\
\hline & Melia dubia (18 inch and above) & $7500-8500$ \\
\hline & & \\
\hline $\begin{array}{l}\text { Vasan Match Works, Vellore; Ideal Splints and Veneers, } \\
\text { Coimbatore }\end{array}$ & Ailanthus excels (24 inch and above) & 5500 \\
\hline $\begin{array}{l}\text { Pavo Energy, Chennai; K.G. Denim Limited, Coimbatore; } \\
\text { Senthil Group of Companies, Coimbatore }\end{array}$ & All agroforestry tree species & $3500-4500$ \\
\hline Bharathi Package and Furniture, Coimbatore & Melia dubia Albizia sp. Acrocarpus fraxinifolius & 8000 \\
\hline
\end{tabular}

harvested, nearly $200-300 \mathrm{~kg}$ of wood bark residue is produced. In timber, plywood and matchwood industries, over $30-40 \%$ of the wood received by the industries is considered as waste in the form of sawdust, chips, wood shavings, etc. which has good potential for value addition. These residues are value-added in the form of briquettes, pellets, charcoal and activated carbon.

\section{Mechanism for tree insurance}

CIAF has links with one of the public sector insurance companies, viz. United India Insurance Company Ltd (UIIC), the second largest general insurance company in the country. Based on mutual consultations and brainstorming, the Consortium has conceived and developed an 'Insurance mechanism' for seven important farm-grown trees ${ }^{16}$. This insurance scheme provides the farmers, treegrowers and captive plantation owners with the much needed relief against the risks/losses faced by them due to biotic and abiotic factors. Table 3 shows the prioritized tree species along with premium and risk coverage factors.

\section{Framework for implementing agroforestry policy in $T N$}

CIAF conducts annual workshops for its enrolled members along with special invitees, which serves as a platform for bringing all the stakeholders in the industrial agroforestry value chain. These annual workshops aid in evaluating the progress made as well as sharing the experiences and constraints faced by the stakeholders. Based on the outcome of the annual workshop, CIAF prioritizes researchable issues for the subsequent year. The
Consortium had also organized an exclusive workshop to prioritize the strategies and guidelines provided in the National Agroforestry Policy in order to develop a framework for adopting and implementing an exclusive agroforestry policy for $\mathrm{TN}$. The recommendations of the workshop were submitted to the Government of TN for adoption and implementation.

\section{Development of unit cost for bankable projects}

CIAF has developed unit cost for four major tree species, viz. Melia dubia (Malabar Neem), Casuarina, kapok and Ailanthus excelsa (Indian tree of heaven) in consultation with its members. The details were forwarded to the National Bank for Agricultural and Rural Development and the insurance agency (UIIC, etc.) for approval and implementation to extend institutional credit and insurance for agroforestry.

\section{Creation of database}

Development of a sound database on the extent and distribution of farm-grown tree species (district-wise and species-wise data), intercrops suitable for cultivation, monthly market prices are also being undertaken by the Consortium, which is being shared among its members.

\section{Research initiatives}

CIAF also conducts a wide range of research initiatives to resolve the issues in PCS. One of the major research initiatives is to inventorize and domesticate new tree species amenable for agroforestry. The Consortium has prioritized 30 tree species suitable for agroforestry and 
Table 3. Details of tree insurance scheme

\begin{tabular}{|c|c|c|}
\hline Prioritized tree species & Premium & Risk coverage \\
\hline $\begin{array}{l}\text { Casuarina } \\
\text { M. dubia } \\
\text { Eucalyptus } \\
\text { A. excelsa } \\
\text { L. leucocephala } \\
\text { Gmelina arborea } \\
\text { Dalbergia sissoo }\end{array}$ & $\begin{array}{l}1.25 \% \text { and } 1.60 \% \\
\text { Rs } 300-800 / \text { acre/year }\end{array}$ & $\begin{array}{l}\text { Forest fire, lightning, animal damage, flood, storm, } \\
\text { cyclone, riots, pests and diseases }\end{array}$ \\
\hline
\end{tabular}

Table 4. Average productivity of High Yielding Short Rotation varieties

\begin{tabular}{llc}
\hline Species & \multicolumn{1}{c}{ Variety } & Productivity (tonnes/ha) \\
\hline Casuarina sp. & TNAU Casuarina MTP2 & 150 \\
Eucalyptus sp. & TNAU Eucalyptus MTP1 & 100 \\
M. dubia & Malaivembu MTP1 (plywood) & 200 \\
& Malaivembu MTP2 (pulp and plywood) & $200-250$ \\
L. leucocephala & FCRILL15 & 100 \\
D. sissoo & DS18 & 150 \\
A. excelsa & MTPAE17 & 200 \\
Neolamarckia cadamba & FCRIAC13 & 100 \\
G. arborea & FCRISS & 200 \\
Tectona grandis & Syyaburry - MTPTK07 & 250 \\
\hline
\end{tabular}

efforts are being taken to develop high-yielding shortrotation clones/varieties (HYSR), designing multifunctional agroforestry models and ensuring adoption of new, emerging technologies by the farmers and stakeholders. Table 4 lists the HYSR clones already developed and promoted through agroforestry.

\section{Impact of activities of the Consortium}

The activities of CIAF have created significant impact in terms of increase in area under agroforestry coupled with improvement in productivity and profitability. It is estimated that these agroforestry initiatives have created 300 man days/ha of employment and augmented productivity to the tune of over $25 \mathrm{~m}^{3} / \mathrm{ha} /$ annum from the baseline level of less than $10 \mathrm{~m}^{3} / \mathrm{ha} /$ annum. It is also estimated that one tonne of wood is equivalent to 0.5 tonnes of carbon sequestered, and thus expansion of agroforestry in TN through the initiatives of CIAF will help reduce carbon load in the atmosphere and address the growing concerns on climate change, besides opening up new vistas of carbon trading for farmers of the state in future.

\section{Way forward}

The Consortium activities are spearheaded by TNAU, whose present reach has expanded outside TN to Karnataka, Kerala, Maharashtra, Telengana, Andhra Pradesh, Madhya Pradesh, Gujarat and Uttar Pradesh. In near future, the activities of CIAF are expected to extend to other states of the country as well. By 2023, CIAF proposes to raise a corpus fund of Rs.10,000,000 (INR 10 million) for sustaining R\&D activities.

\section{Summary}

CIAF was established by TNAU with the purpose of identifying the constraints and harnessing the potential in agroforestry sector. This Consortium aims to resolve the issues through strong $R \& D$ programmes coupled with timely dissemination of improvements realized to the treegrowing farmers. Various issues, viz. availability of quality planting material, organized plantation development, issues related to supply chain process and value-addition possibilities are addressed through the Consortium, which has propelled this institution to play a significant role in agroforestry promotion in TN. Linkage of various stakeholders in one platform through the Consortium has ensured a strong public-private partnership mode of operation and resulted in increasing the trees outside forests in $\mathrm{TN}$, besides successfully meeting the domestic and industrial wood requirements. Consortium-mode agroforestry promotion is a model approach for adoption across the country to create self-reliance in raw material security, besides catering to the needs of climate change.

1. Parthiban, K. T., Vennila, S., Kumar, P., Saravanan, V. and Subbulakshmi, V., Industrial Agroforestry - a value chain approach in Tamil Nadu. In Industrial Agroforestry-Perspectives 
and Prospectives (eds Parthiban, K. T. et al.), Scientific Publishers (India), Jodhpur, 2014, pp. 7-32.

2. FAO, India forestry outlook study. Working Paper No. APFSOS II/WP/2009/06. Food and Agricultural Organisation, Ministry of Environment and Forests, Government of India (GoI), 2009.

3. Food and Agriculture Organization of the United Nations database, 2013; http://faostat.fao.org/.

4. Knickel, K., Agricultural structural change: impact on the rural environment. J. Rural Sci., 1990, 6(4), 383-393.

5. Leakey, R. R. B. and Sanchez, P. A., How many people use agroforestry products? Agrofor. Today, 1997, 9(3), 4-5.

6. Izac, A. M. N. and Sanchez, P. A., Towards a natural resource management research paradigm: an example of agroforestry research. Agric. Syst., 2001.

7. Zomer, R. J., Trabucco, A., Coe, R., Place, F., van Noordwijk, M. and $\mathrm{Xu}, \mathrm{J}$., Trees on farms: an update and reanalysis of agroforestry's global extent and socio-ecological characteristics. World Agroforestry Centre (ICRAF) South Asia Regional Program, Working Paper No. 179, 1999.

8. Xu, D., Forestry and land use change assessment for China. In Forestry and Land Use Change Assessment, Asian Development Bank, Manila, Philippines, 1999, pp. 73-97.

9. IPCC, Climate change impacts on forests. In Climate Change 1995: Impacts, Adaptations and Mitigation of Climate Change: Scientific-Technical Analyses. Contribution of Working Group II to the Second Assessment Report of the Intergovernmental Panel on Climate Change (eds Watson, R. T., Zinyowera, M. C. and
Moss, R. H.), Cambridge University Press, Cambridge, UK, 1996, p. 879 .

10. Bargali, S. S., Bargali, K., Singh, L., Ghosh, L. and Lakhera, M. L., Acacia nilotica based traditional agroforestry system: effect on paddy crop and management. Curr. Sci., 2009, 96(4), 581-587.

11. Parihaar, R. S., Bargali, K. and Bargali, S. S., Status of an indigenous agroforestry system: a case study in Kumaun Himalayas, India. Indian J. Agric. Sci., 2015, 85(3), 442-447.

12. Vibhuti, Bargali, K. and Bargali, S. S., Effects of homegarden size on floristic composition and diversity along an altitudinal gradient in Central Himalaya, India. Curr. Sci., 2018, 114(12), 2494-2503.

13. Anon., National Forest Policy, Ministry of Environment and Forests, GoI, N1988.

14. Parthiban, K. T. and Cinthia Fernandaz, C., Industrial agroforestry - status and developments in Tamil Nadu. Indian J. Agroforestry., 2017, 19(1), 1-11.

15. Anon., National Agroforestry Policy. Ministry of Agriculture and Cooperation, GoI, 2014

16. Parthiban, K. T., Industrial agroforestry: a successful value chain model in Tamil Nadu, India. In Agroforestry Research Developments, Nova Science Publishers Inc, New York, USA, 2016, pp. 523-537.

Received 6 July 2018; revised accepted 2 April 2019

doi: $10.18520 / \mathrm{cs} / \mathrm{v} 117 / \mathrm{i} 1 / 30-36$ 